\title{
Decay Patterns in Silver Maple (Acer saccharinum) Trees Converted from Roundovers to V-Trims
}

\author{
Gregory A. Dahle, Harvey H. Holt, William R. Chaney, Timothy M. Whalen, Jason Grabosky, \\ Daniel L. Cassens, Rado Gazo, Rita L. McKenzie, and Judith B. Santini
}

\begin{abstract}
Trees growing beneath electrical power lines are often subjected to heading cuts made during roundover trimming. Heading cuts create wounds that allow decay to enter the branch, and a decay column will form if the tree does not contain it with compartmental reaction zones. The presence of a sizable decay column may predispose the leader to failure, especially when the tree has been converted from a roundover to a V-trim. The objectives of this study were to quantify the amount of decay in silver maples (Acer saccharinum L.) converted from roundover to V-trims and to develop models to allow utility arborists to estimate the extent of internal decay columns. Parent stems (leaders) were removed from converted trees, cut into $50 \mathrm{~cm}$ (20 in) sections, and measured for internal and external decay. Eighty percent of the leaders had internal decay columns beginning within $50 \mathrm{~cm}$ (20 in) of the heading cut and internal decay columns were found to be over $2 \frac{1}{2}$ times longer than the length of external decay. Models are presented to predict the length and volume of internal decay from external measurements on the leader, including length of external decay.
\end{abstract}

Key Words. Acer saccharinum; heading cuts; line clearance; roundover; utility arboriculture; V-trimming; wood decay.

The principal goals of utility line clearance operations are to maintain safe and reliable electric power. Utilities must regularly trim trees that interfere with their power lines (Johnstone 1983; Browning and Wiant 1997). Trees growing beneath power lines are often subjected to roundover trimming to maintain clearance from the conductors. In an effort to reduce costs, many utilities have adopted directional pruning techniques that leave portions of the canopy to grow untrimmed while maintaining desired conductor clearances. V-trimming is a type of directional pruning in which the exterior portions of the canopy remain, whereas the center is periodically trimmed (Johnstone 1983; Gilman 2002).

Roundover trees are subjected to heading cuts in which the branch is cut to a predetermined location not associated with a lateral branch or bud (American National Standards Institute 2001; Gilman 2002). Heading cuts also remove a large portion of the canopy, thus drastically reducing photosynthesis and available carbohydrates (Kaiser et al. 1986; Fazio and Krumpe 1999). Many trees respond to extensive pruning by producing numerous fast-growing watersprouts. The energy to produce the watersprouts is drawn from stored carbohydrates that would otherwise be used in forming barriers to protect the tree from invading decay organisms.

If a tree is inherently prone to decay, or cannot form adequate reaction zones, decay will likely spread down the parent stem (leader), creating decay columns. The conversion from roundover to V-trim establishes a canopy that increases in size and weight over time. The presence of a sizable decay column may predispose the leader to failure as the new canopy grows in size. Indeed, $20 \%$ of watersprouts failed along decayed leaders when they were subjected to static loading tests (Dahle et al. 2006a).

The objectives of this study were to (1) quantify the amount of decay in silver maples (Acer saccharinum L.) converted from roundover to V-trims and (2) develop models to allow utility arborists to estimate the extent of internal decay columns.

\section{METHODS}

Silver maple trees located in Tippecanoe County in central Indiana, U.S., were used in this study. The trees had been subjected to heading cuts (roundovers) followed by an ongoing conversion to V-trims during electrical line clearance operations, likely two to three trim cycles or 6 to 12 years (Dahle et al. 2006b). Sampling occurred between July and October 2002.

Six trees were sampled with diameters at breast height (dbh) (measured $137.2 \mathrm{~cm}$ [54.9 in] above grade) ranging from 34 to $71 \mathrm{~cm}$ (13.6 to 28.4 in). Trees were disassembled with a chain saw and leaders were cut into $50 \mathrm{~cm}$ (20 in) long sections and the diameter (outside bark) was measured at both ends of the section. The diameter of internal decay visible on 
the cross-sectional face of each section was measured. The extent of decay was determined by probing with a sharp knife for a boundary between the weakened decayed wood and stronger normal wood. The average of two perpendicular measurements was used as the diameter of decay.

The volume for each $50 \mathrm{~cm}$ (20 in) long section was calculated using the formula for a frustum of a right circular cone (Equation 1). When decay was present on both ends, the frustum formula was used to calculate the volume of decay. If decay was only present on one end of the section, the right circular formula for cone (Equation 2) was used to estimate decay volumes.

Equation 1: Volume of the frustum of a right circular cone

$$
\text { Volume }=\frac{\pi\left(r^{2}+r R+R^{2}\right) h}{3}
$$

where: $r=$ smaller radii

$R=$ larger radii, and

$h=$ length of section

Equation 2: Volume of a right circular cone

$$
\text { Volume }=\frac{\pi r^{2} h}{3}
$$

where: $r=$ radius

$h=$ section length $/ 2$

Data were analyzed using analysis of variance (ANOVA), and a least significant difference (LSD) procedure for unequal sample size was used to determine differences between the means for the beginning distance of external and internal decay. Stepwise regression analysis was used to determine linear relationships in the data using the following variables: diameter at the tip (distal), diameter at trunk (proximal), diameter of decay at the tip, diameter decay at trunk, length of external decay, length of internal decay, first-order interactions, and the square of first-order variables. ANOVA, regression analyses, and calculations of $95 \%$ prediction intervals were run using the SAS System version 8.2 (SAS 1999), and LSD were calculated by hand to adjust for unequal sample size. During the stepwise procedure, significance levels for variable selection were set at $15 \%$ to allow for variation as variables were added or removed. Significance levels for all final models were set at 5\% $(\alpha=0.05)$. Percentage of volume loss was calculated then transformed using the square root before statistical analysis. Predicted values for regression models are presented in which the length of external decay along the leader was allowed to vary and the remaining variables were fixed with their corresponding mean value.

\section{RESULTS}

Internal decay columns began at the heading cut in $46 \%$ of the leaders within 1 to $50 \mathrm{~cm}$ ( 0.4 to 20 in) from the heading cut in $33 \%$ of the leaders more than $50 \mathrm{~cm}$ (20 in) from the heading cut in $10 \%$ of the leaders, whereas $10 \%$ of the leaders had no decay (Table 1A). External decay began in the first 50 $\mathrm{cm}$ (20 in) section in 59\% of the leaders, from 51 to $100 \mathrm{~cm}$ (20.4 to 40 in) in $7 \%$ of the leaders, greater than $100 \mathrm{~cm} \mathrm{(40}$ in) in $13 \%$ of the leaders, and no decay was present in $20 \%$ of the leaders (Table 1B).

A highly significant difference $(P<0.001)$ was found between the total length of internal decay $(142.7 \mathrm{~cm}$ [57.1 in] and standard error $[\mathrm{SE}]=11.2,56.2 \mathrm{in}$, and $\mathrm{SE}=4.4)$ and external decay (50.6 cm [20.2 in] and $\mathrm{SE}=7.7,19.9$ in and $\mathrm{SE}=3.0$ ). No significant relationships were found between the distance at which internal decay began from the heading cut in the leaders and either the diameter of the leader at the heading cut $(P=0.316)$ or the total length of internal decay $(P=0.301)$. A highly significant relationship was found for the total length of internal decay in the leader and four measurements: the length of external decay, beginning and ending leader diameter, and leader length $\left(\mathrm{R}^{2}=0.45, P<0.001\right)$ (Regression 1). Figure 1 depicts a set of predicted values and 95\% prediction interval for the length of internal decay using regression 1 , where $X_{2}=14 \mathrm{~cm}(5.6 \mathrm{in}), X_{3}=22 \mathrm{~cm}(8.8$ in), and $X_{4}=251 \mathrm{~cm}(100.4 \mathrm{in})$.

A highly significant relationship was found between the volume of decay in the leaders and three variables: the length of external decay, beginning and ending diameter of the leader $\left(\mathrm{R}^{2}=0.90, P<0.001\right)$ (Regression 2). A set of predicted values and $95 \%$ prediction interval for volume of decay using Regression 2 are shown in Figure 2, where $X_{2}=14$ $\mathrm{cm}(5.6 \mathrm{in})$ and $\mathrm{X}_{3}=22 \mathrm{~cm}$ (8.8 in).

Table 1. Percentage of parent stems (leaders) in each distance class $(\mathrm{cm})$ in which $(A)$ internal and $(B)$ external decay began from the heading cut in silver maple leaders converted from roundover to $\mathrm{V}$-trims during electrical line clearance operations.

\begin{tabular}{lll}
\hline \multicolumn{3}{c}{ A. Internal decay } \\
\hline Distance $(\mathrm{cm})$ & No. of leaders & Percentage with decay \\
\hline 0 & 32 & 46.4 \\
1 to 50 & 23 & 33.3 \\
$>50$ & 7 & 10.1 \\
No decay & 7 & 10.1 \\
\hline \multicolumn{3}{c}{ B. External decay } \\
\hline Distance $(\mathrm{cm})$ & No. of leaders & Percentage with decay \\
\hline 0 to 50 & 41 & 59.4 \\
51 to 100 & 5 & 7.2 \\
$>100$ & 9 & 13.0 \\
No decay & 14 & 20.3 \\
\hline
\end{tabular}




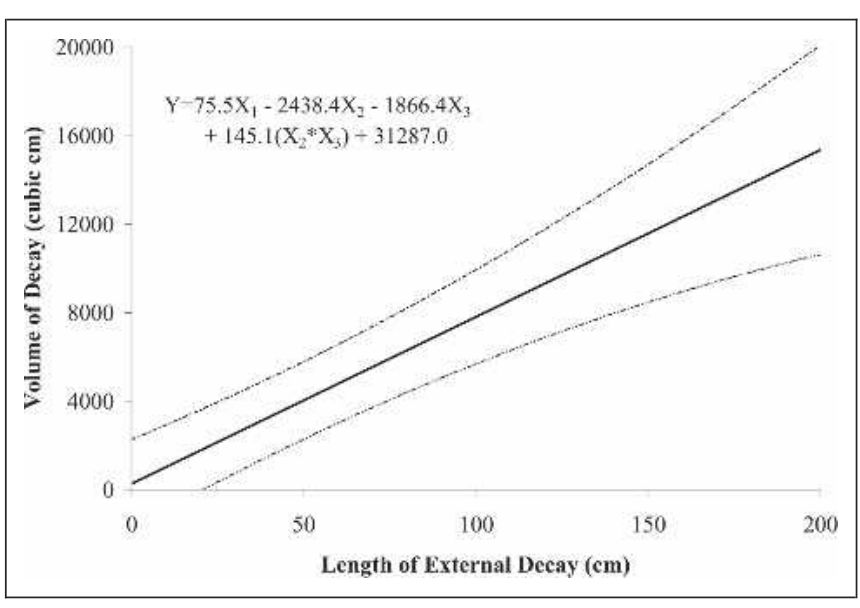

Figure 1. Regression relationship and $95 \%$ prediction interval for the length of internal decay $(\mathrm{cm})$ of leaders and length of external decay $\left(X_{1}\right)$ in centimeters at leader diameter at the heading cut $\left(X_{2}\right)$ of $14 \mathrm{~cm}(5.6 \mathrm{in})$, leader diameter at the base $\left(X_{3}\right)$ of $22 \mathrm{~cm}(8.8 \mathrm{in})$, and leader length $\left(X_{4}\right)$ of $251 \mathrm{~cm}(100.4 \mathrm{in})$ in silver maple trees converted from roundover to $\mathrm{V}$-trims during electrical line clearance operations. $R^{2}$ for the regression model was 0.45 .

Regression 1:

length of internal decay $=0.033\left(\mathrm{X}_{1} \mathrm{X}_{2}+0.008\left(\mathrm{X}_{3} \mathrm{X}_{4}\right)\right.$

$$
+86.017
$$

Regression 2:

$$
\begin{aligned}
\text { volume of decay }= & 75.5 \mathrm{X}_{1}-2438 . \mathrm{X}_{2}-1866.4 \mathrm{X}_{3} \\
& +145.1\left(\mathrm{X}_{2} \mathrm{X}_{3}\right)+31287.0
\end{aligned}
$$

Regression 3:

square root $($ percent volume loss $)=0.001 \mathrm{X}_{1}+0.012 \mathrm{X}_{5}$

$$
+0.116
$$

where: $\mathrm{X}_{1}=$ length $(\mathrm{cm})$ of external decay

$\mathrm{X}_{2}=$ leader diameter $(\mathrm{cm})$ at the heading cut

$\mathrm{X}_{3}=$ leader diameter $(\mathrm{cm})$ at the base

$\mathrm{X}_{4}=$ leader length $(\mathrm{cm})$

$\mathrm{X}_{5}=$ diameter decay $(\mathrm{cm})$ at heading cut

The mean volume of the exterior shell of the leader was $65,984.7 \mathrm{~cm}^{3}\left(4,026.6 \mathrm{in}^{3}\right)$, and mean volume of decay was $5,528.4 \mathrm{~cm}^{3}\left(337.4 \mathrm{in}^{3}\right)$, leaving $60,456.3 \mathrm{~cm}^{3}\left(3,689.2 \mathrm{in}^{3}\right)$ of sound wood. Mean percent volume loss was $8.4 \%$. Percent volume loss to decay was highly significantly different among 3 distance to initial decay groups $(P=0.002)$. The percent volume loss $(9 \%)$ at the heading cut $(0 \mathrm{~cm})$ was different from both beginning distances of 1 to $50 \mathrm{~cm}(0.4$ to 20 in) from the heading cut (3\%) and greater than $50 \mathrm{~cm}(20$ in) from the heading cut $(2 \%)$, yet no difference was found between the 1 to $50 \mathrm{~cm}$ ( 0.4 to 20 in) distance and the greater than $50 \mathrm{~cm}$ (20 in) distance. A highly significant relationship was found for the square root of percent volume loss and 2 variables: the length of external decay and diameter of decay at the heading cut $\left(\mathrm{R}^{2}=0.57, P<0.001\right)($ Regression 3$)$.

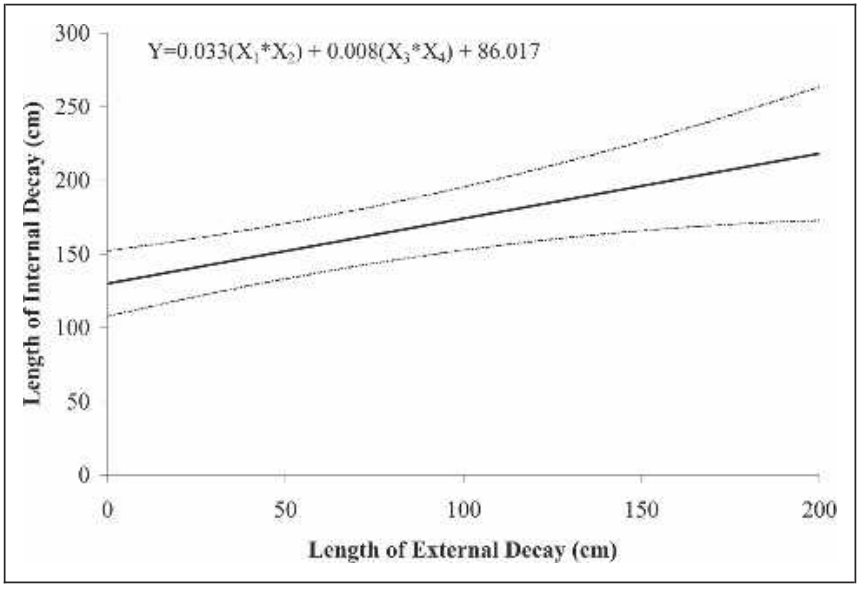

Figure 2. Regression relationship and $95 \%$ prediction interval for the volume of internal decay $\left(\mathrm{cm}^{3}\right)$ of leaders and length of external decay $\left(X_{1}\right)$ in centimeters at leader diameter at the heading cut $\left(X_{2}\right)$ of $14 \mathrm{~cm}(5.6 \mathrm{in})$ and leader diameter at the base $\left(X_{3}\right)$ of $22 \mathrm{~cm}(8.8 \mathrm{in})$ in silver maple trees converted from roundover to $\mathrm{V}$-trims during electrical line clearance operations. $R^{2}$ for the regression model was $\mathbf{0 . 8 2}$.

Figure 3 depicts a set of predicted values and the 95\% prediction interval for percent volume loss in the leaders using Regression 3 where $X_{5}=4 \mathrm{~cm}$ (1.6 in).

\section{DISCUSSION}

Ninety percent of the leaders were found to contain decay columns (Dahle et al. 2006a), and it appears that decay is often directly associated with heading cuts, because $46 \%$ of the leaders had decay at the distal end (Table 1A). Furthermore, the majority of the leaders $(80 \%)$ had internal decay within the first $50 \mathrm{~cm}$ (20 in) from the heading cut. Internal decay columns not associated with heading cuts were most likely the result of the onset of decay from external sources, either old pruning wounds or from cambial dieback caused by sunburn (Costello et al. 2003).

External decay was seen in $80 \%$ of the leaders (Dahle et al. 2006a) and typically began within the first $50 \mathrm{~cm}$ (20 in) from the heading cut (Table 1B). The overall length of internal decay was found to be over $2 \frac{1 / 2}{2}$ times that of external decay. The presence of external decay can be an important tool in estimating the size of an internal decay column. The predicted length of internal decay increased with the length of the leader, length of external decay, and with the diameter of both ends of the leader (Figure 1). The relationship between internal decay and the lengths of the leader and external decay seems logical. That internal decay increased as the diameter of the leader increased is noteworthy because it shows that leaders larger in cross-sectional area will have longer decay columns. This suggests that silver maple is not a good compartmentalizer and is susceptible to heartwood decay. 


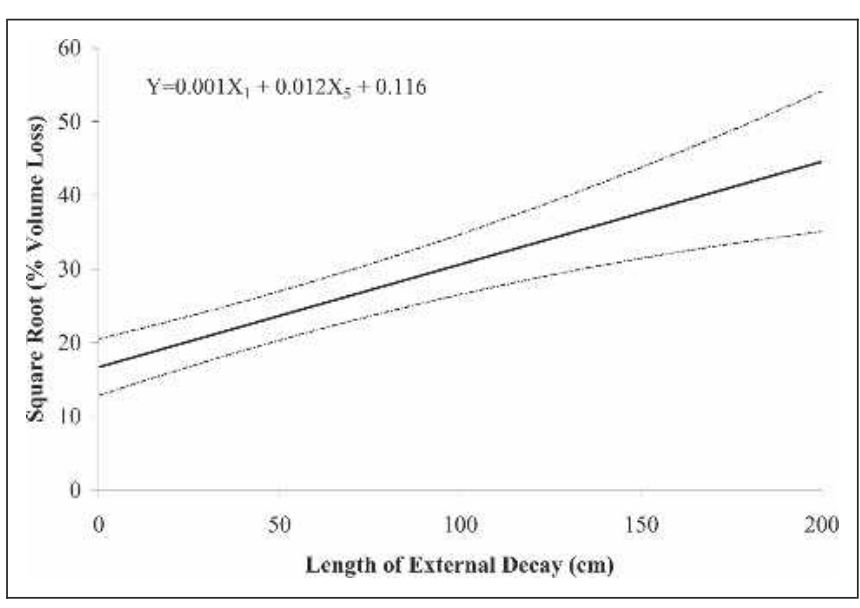

Figure 3. Regression relationship and $95 \%$ prediction interval for the square root of percent volume loss resulting from decay of leaders and length of external decay $\left(X_{1}\right)$ in centimeters at diameter decay at heading cut $\left(X_{5}\right)$ of $4 \mathrm{~cm}$ (1.6 in) in silver maple trees converted from roundover to $\mathrm{V}$-trims during electrical line clearance operation. $\mathbf{R}^{2}$ for the regression model was $\mathbf{0 . 5 7}$.

Indeed, Giles (2001) lists silver maple heartwood as having a low resistance to decay.

The predicted volume of decay also increased with the length of external decay and diameter of the two ends of the leader (Figure 2). Percentage of volume loss was found to be three times greater in leaders in which internal decay began at the heading cut and increased as the length of external decay and diameter of decay the heading cut increased (Figure 3). Because nearly half the leaders had decay at the tip, it seems reasonable to suggest that heading cuts are likely to create sizable decay columns, which may cause the leaders to become susceptible to failure.

Although no direct relationship to strength loss can be inferred from the regressions presented here, utility arborists may want to use the equations to estimate the extent of internal decay columns in silver maple trees. Estimating internal decay from the presence of external decay can be a useful tool when deciding on failure risk levels in trees converted from roundovers to V-trims. A better understanding of the amount of decay present in the leaders will help arborists determine whether the risk of failure is high enough to warrant the removal of a leader or the whole tree. Future research should investigate if the patterns of decay are similar in other tree species.

Acknowledgments. The authors thank Purdue University, the Department of Forestry and Natural Resources, and the TREE Fund for financial support. PSI Cinergy and Tipmont REMC donated tree crew time. Finally, the authors appre-

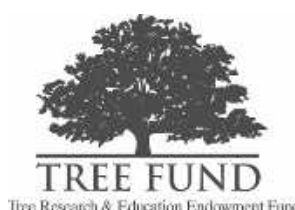
ciate the suggestions provided by the anonymous reviewers; the manuscript is stronger with their help.

\section{LITERATURE CITED}

American National Standards Institute. 2001. American National Standards for Tree Care Operations-Tree, Shrub, and Other Woody Plant Maintenance-Standard Practices (Punning) (A300, Part 1). Tree Care Industry Association, Manchester, NH.

Browning, D.M., and J.V. Wiant. 1997. The economic impacts of deferring electric utility tree maintenance. Journal of Arboriculture 23:106-111.

Costello, L.R., E.J. Perry, N.P. Matheny, J.M. Henry, and P.M. Geisel. 2003. Abiotic Disorders of Landscape Plants: A Diagnostic Guide. University of California Agriculture and Natural Resources. Oakland, CA. 242 pp.

Dahle, G.A., H.A. Holt, W.R. Chaney, T.M. Whalen, D.L. Cassens, R. Gazo, and R.L. McKenzie. 2006a. Implications of branch strength loss in silver maple trees converted from round-over to V-trims during electrical line clearance operations. Proc. Environmental Concerns in Rights-of-Way Management Eighth International Symposium (In press).

- 2006b. Branch strength loss implications for silver maple (Acer saccharinum) converted from round-over to V-trim. Arboriculture \& Urban Forestry 32(4):148-154.

Fazio, J.R., and E.E. Krumpe. 1999. Underlying beliefs and attitudes about topping trees. Journal of Arboriculture 25: 193-199.

Giles, R.J. 2001. A total forest management plan and wildland management decision support system. Virginia Polytechnic Institute and State University, Blacksburg, VA. http://fwie.fw.vt.edu/rhgiles/Trevey/forSnags.htm (accessed 9/27/06).

Gilman, E.F. 2002. An Illustrated Guide to Pruning. Delmar, Albany, NY. 330 pp.

Johnstone, R.A. 1983. Management techniques for utility tree maintenance. Journal of Arboriculture 9:17-20.

Kaiser, C.A., M.L. Witt, J.R. Hartman, R.E. McNeil, and W.C. Dunwell. 1986. Warning: Topping is hazardous to your trees health. Journal of Arboriculture 12:50-52.

SAS Institute Inc. 1999. SAS/STAT User's Guide, Version 8. SAS Institute Inc., Cary, NC 3884 pp.

Gregory A. Dahle (corresponding author)

Research Assistant

14 College Farm Road

Department of Ecology, Evolution \& Natural Resources

Rutgers University

New Brunswick, NJ 08901-8551, U.S.

gdahle@eden.rutgers.edu

Harvey H. Holt

Professor of Forestry

195 Marsteller Street

Department of Forestry \& Natural Resources

Purdue University

West Lafayette, IN 47907-2033, U.S. 
William R. Chaney

Professor Emeritus of Tree Physiology

715 West State Street

Department of Forestry \& Natural Resources

Purdue University

West Lafayette, IN 47907-2061, U.S.

Timothy M. Whalen

Assistant Professor of Engineering

550 Stadium Mall Drive

School of Civil Engineering

Purdue University

West Lafayette, IN 47907-2051, U.S.

Jason Grabosky

Associate Professor of Urban Forestry

14 College Farm Road

Department of Ecology, Evolution \& Natural Resources

Rutgers University

New Brunswick, NJ 08901-8551, U.S.

Daniel L. Cassens

Professor of Wood Products

1200 Forest Products Building

Department of Forestry \& Natural Resources

Purdue University

West Lafayette, IN 47907-1200, U.S.

Rado Gazo

Associate Professor of Wood Processing

1200 Forest Products Building

Department of Forestry \& Natural Resources

Purdue University

West Lafayette, IN 47907-1200, U.S.

Rita L. McKenzie

Urban Forester

195 Marsteller Street

Department of Forestry \& Natural Resources

Purdue University

West Lafayette, IN 47907-2033, U.S.

Judith B. Santini

Research Statisical Analyst

915 W. State Street

Department of Agronomy

Purdue University

West Lafayette, IN 47907-2054, U.S.

Résumé. Les arbres qui poussent sous les réseaux électriques sont souvent étêtés lors des tournées cycliques de dégagement. Les étêtages créent des blessures qui permettent à la carie de pénétrer dans les branches et de créer des colonnes de pourriture si l'arbre ne peut contenir ce processus par la compartimentation. La présence d'une colonne importante de carie peut prédisposer la branche terminale au bris, particulièrement lorsque la cime de l'arbre a été transformée d'une forme arrondie à une forme en V. Les objectifs de cette étude sont de quantifier le taux de carie chez les érables argentés (Acer saccharinum L.) lorsque la cime de ces derniers passe d'une forme globulaire à une en $\mathrm{V}$, et ce afin de développer des modèles qui permettront aux arboriculteurs du réseau d'estimer le degré d'importance des colonnes de carie interne. Des branchesmères terminales ont été coupées sur des arbres élagués en $\mathrm{V}$, redécoupées en sections de $50 \mathrm{~cm}$ de longueur et ont été mesurées en regard des taux de carie interne et externe. Quatre-vingt pourcent des branches terminales comportaient des colonnes de carie interne qui débutaient à l'intérieur des 50 premiers centimètres sous la coupe; de plus, les colonnes de carie interne étaient 2-1/2 fois plus longues que la longueur des zones de carie externe. Des modèles sont présentés afin de prédire la longueur et le volume de la zone de carie interne à partir de mesures externes sur la branche terminale, et ce en incluant la longueur de la zone de carie externe.

Zusammenfassung. Bäume, die unter Elektroleitungen wachsen, sind bei den Freischnitten oft von Kopfschnitten betroffen. Kopfschnitte verursachen Wunden, die Fäulniserregern den Eintritt in Äste ermöglichen, so dass sich ein Fäulniskegel bilden kann, wenn der Baum nicht in der Lage ist, Barrierezonen aufzubauen. Ein solcher Fäulniskegel kann den Leittrieb zum Abknicken bringen, besonders wenn eine runde Krone zu einer V-förmigen Krone umgeschnitten wurde. Die Ziele dieser Studie lagen in der Quantifizierung von Fäulnis in Silberahornen, die von rund auf v-förmig geschnitten wurden und bei der Entwicklung von Modellen zur Bestimmung von dem Ausmaß innerer Fäule. Von den umgeformten Bäumen wurden die Leittriebe entfernt, in $50 \mathrm{~cm}$ lange Sektionen unterteilt und auf Anzeichen interner und externer Fäulnis untersucht. $80 \%$ der Leittriebe hatten interne Fäule innerhalb der ersten $50 \mathrm{~cm}$ vom Kopfschnitt und die internen Fäulniskegel waren 2,5-fach so lang wie die äußeren Fäulniserscheinungen. Hier werden Modelle vorgestellt, um die Länge und das Ausmaß von interner Fäule anhand von äußeren Messungen der Leittriebe und der externen Fäule zu bestimmen.

Resumen. Los árboles que crecen bajo líneas energizadas están con frecuencia sometidos a descabezados hechos durante las cortas para reducir su copa. Los descabezados crean heridas que permiten que la descomposición entre a la rama y se forme una columna de decaimiento, si los árboles no las contienen con zonas de compartimentación. La presencia de dicha columna puede predisponer a la falla de la rama líder, especialmente cuando el árbol ha sido convertido de una forma redondeada a una en forma de V. Los objetivos de este estudio fueron cuantificar la cantidad de decaimiento en maples (Acer saccharinum L.) convertidos de forma redondeada a forma de $\mathrm{V}$ y desarrollar modelos que permitan a los arboristas estimar la extensión de las columnas de decaimiento interno. Las ramas parentales (líderes) fueron removidas de los árboles tratados, cortadas en secciones de $50 \mathrm{~cm}$. y se midió el decaimiento interno y externo. El ochenta por ciento de las líderes tuvieron columnas de decaimiento interno, empezando dentro de $10 s 50 \mathrm{~cm}$. de la corta de descabezado, y esta columnas fueron $2 \frac{1}{2} 2$ veces más largas que la longitud del decaimiento externo. Se presentan modelos para predecir la longitud y el volumen del decaimiento interno a partir de las mediciones externas sobre la líder, incluyendo la longitud del decaimiento externo. 